\title{
A Heritage Agronomic Study as a Database for Monitoring the Soil Salinity of an Irrigated District in NE Spain
}

\author{
Juan Herrero $^{1, *(\mathbb{D}}$, Carmen Castañeda ${ }^{1} \mathbb{D}$ and Rosa Gómez-Báguena ${ }^{2}$ \\ 1 Estación Experimental de Aula Dei, CSIC, Ave. Montañana 1005, 50059 Zaragoza, Spain; \\ ccastaneda@eead.csic.es \\ 2 Centro de Investigación y Tecnología Agroalimentaria de Aragón (CITA), Unidad de Suelos y \\ Riegos (Associated with EEAD-CSIC), Ave. Montañana 930, 50059 Zaragoza, Spain; rgomezb@aragon.es \\ * Correspondence: jhi@eead.csic.es
}

Citation: Herrero, J.; Castañeda, C.; Gómez-Báguena, R. A Heritage Agronomic Study as a Database for Monitoring the Soil Salinity of an Irrigated District in NE Spain Agronomy 2022, 12, 126. https:// doi.org/10.3390/agronomy12010126

Academic Editors: Othmane Merah, Purushothaman

Chirakkuzhyil Abhilash, Magdi

T. Abdelhamid, Hailin Zhang and Bachar Zebib

Received: 23 December 2021 Accepted: 29 December 2021 Published: 5 January 2022

Publisher's Note: MDPI stays neutral with regard to jurisdictional claims in published maps and institutional affiliations.

Copyright: (C) 2022 by the authors. Licensee MDPI, Basel, Switzerland. This article is an open access article distributed under the terms and conditions of the Creative Commons Attribution (CC BY) license (https:// creativecommons.org/licenses/by/ $4.0 /)$.

\begin{abstract}
This article presents and reviews the soil salinity data provided by a rescued vintage agronomic report on an irrigated area of 35,875 ha located in the center of the Ebro River basin, in the $\mathrm{NE}$ of mainland Spain. These data come from a soil sampling campaign conducted from May to the first half of July 1975 for the purpose of delineating saline and non-saline soils. The agronomic report was produced in response to demands from farmers to combat soil salinity, and represents the state of the art in those years for salinity studies. Our paper presents the scrubbed soil salinity data for this year, checking their consistency and locating the study sites. The main finding is the unearthing of this heritage report and the discussion of its soil salinity data. We show that the report supplies an assessment and a baseline for further soil salinity tracking by conducting new measurements either by direct soil sampling or by nondestructive techniques, providing an estimate of soil salinity at different locations. This task is feasible, as shown in our previously published articles involving nearby areas. A comparison of the salt amount in the soil over the years would provide a means to evaluate irrigation methods for sustainable land management. This comparison can be conducted simultaneously with analysis of other agricultural features described in the report for the irrigation district in 1975.
\end{abstract}

Keywords: aridity; Ebro river basin; irrigation; soil salinity tracking

\section{Introduction}

Soil salinity is often a threat to the sustainability of irrigated agriculture in dry climates [1,2], and current global maps are out of date and incomplete, e.g., GSASmap [3]. Of all the European countries, Spain has the most inland salt-affected agricultural land, mainly located in the Central Ebro Basin (CEB), as shown in the map compiled by [4]. The agricultural problem of soil salinity in Spain was studied early on by scientists [5], agronomists [6,7] and economists [8,9], and is well-known to farmers and engineers, as evidenced by the references quoted in [10]. Some irrigated soils were saline, or became so after irrigation works. However, most of the studies with a broad geographical scope, e.g., [11], do not address this subject, probably due to the paucity of reliable measurement-based data on trends in soil salinity. This scarcity, or even absence, also occurs in other irrigated areas [12] hampering the local application of long-term studies on soil salt-affection. Given this scarcity, most of these studies rely almost exclusively on remote sensing and are used for comparisons, e.g., $[13,14]$.

Land irrigation in the CEB required large investments to build reservoirs, transport and distribute water through hundreds of kilometers of canals, level land, and build plots with the appropriate shape, size and slope for the available irrigation techniques. These works started in the 1920s [15], with investments now focusing on shifting from basin and border irrigation to pressurized and automated irrigation systems. These efforts and the 
current challenges to agriculture merit an evaluation of the agronomic and environmental effects of irrigation. It is possible to determine the volume and spatial distribution of the water applied by irrigation, even in hindsight [16]. By contrast, few data are available on the trend in soil salinity, despite this being a major threat to the sustainability of agriculture, as well as an easily variable property of soils, and a prime feature for land evaluation in the CEB [17]. When assessing the temporal variation of soil salinity, legacy information is of paramount interest [18-20] for comparison with new data and for addressing new policy concerns [21]. These comparisons would bring farmers closer to the multifunctional use of land described by [22], without neglecting the primary productivity. The acquisition of data on soil salinity is being made increasingly affordable through the use of proximal sensors [23-25], the combined measurement of water and salt contents in the soil [26], and wireless monitoring [27].

\section{The Context of the 1975 Report}

Soil salinity is an old problem affecting both agriculture and the environment in irrigated lands at CEB. The irrigation water, conveyed by a network of canals from snowpack in the Pyrenees, has a low electrolyte content. Lime is frequent everywhere in the soils and parental materials, with some areas also containing gypsum. The shales are often saliferous. The soil salinity results from salts rising from the Miocene saliferous materials often brought to the surface by land leveling and other works. The meteoric and irrigation waters redistribute the salts, which undergo evapoconcentration in the soil.

For mainland Spain, [10] listed a number of agronomical reports prepared by the INC (National Institute of Colonization) or by its successor IRYDA (National Institute for Agrarian Reform and Development). Both now-defunct bodies were in charge of the design, construction and implementation of the new irrigation districts in Spain, starting in the 1940s. Through the early 1980s, these bodies produced a wealth of reports that are now difficult to access. Moreover, time and inappropriate storage resulted in some reports becoming illegible due to fading ink, paper degradation, and/or toner detachment, as noted by [28]. The surviving copies need to be scanned and stored in public repositories [10]. In the meantime, we retrieved the data from some of these reports [29-31].

Herein, we study the data on soil salinity, as expressed by the measurements of its electrical conductivity contained in a two-volume agronomical report with a total of about 800 pages commissioned by IRYDA $[32,33]$. The report deals with an irrigated district watered by the 2 nd and 3rd sections of the first stretch of Monegros Canal, with a flow capacity of $70 \mathrm{~m}^{3} \mathrm{~s}^{-1}$. The irrigated district, located in the province of Huesca, Spain, corresponds to soil study No. 60 of 89 in the Ebro basin listed by IRYDA and shown in [34]. For brevity, we will call the district "IRYDA_Monegros1".

The absence of a framework for determining soil status [35] makes multitemporal comparisons even rarer. As stressed by [36], changes in soil properties within the timescales of policy reviews are difficult to measure. Soil salinity, a highly dynamical characteristic of irrigated soils, is probably a notable exception. We do not attempt herein to establish the trend in salinization or desalinization between different dates, but to pave the way for doing so by encouraging the stakeholders to allocate the necessary funds and personnel. In keeping with Sumner [18], we " ... focus on the legacy of forgotten, lost, or discarded information and knowledge that can be applied to improve the future in a predictable way."

The aim of this paper is to recover and make public a heritage document containing a large amount of data, and to review and summarize the information on soil salinity in 1975 provided by the IRYDA report $[32,33]$ in order to facilitate its use for comparative studies.

\section{Temporal and Geographical Setting}

Many of the irrigation districts built from the 1940s to the early 1980s by INC and IRYDA transitioned in subsequent decades from basin and border irrigation to pressurized and automated water application [37], a process that is still ongoing. Most of the work to transform wide tracts of arid land through irrigation started in the 1940s, as is the case of 
the "IRYDA_Monegros1" district. These works included land leveling and systematization, secondary canals, roads, and new villages for families to settle, which included vegetable gardens and recreational groves. Some of the earth movements brought to the surface the underlying saliferous geological materials, resulting in soil salinization [29].

The Monegros Canal, with a length of $133 \mathrm{~km}$, is a prominent infrastructure for transferring water collected in the Pyrenees to the semiarid CEB. After the Monegros and Cinca canals were connected, the irrigated surface totaled 110,000 ha, with a planned surface area of 185,000 ha at the completion of the Monegros-Cinca system (www.chebro.es, accessed on 22 December 2021).

The "IRYDA_Monegros1" irrigation district (Figure 1A) is bounded by: (i) the Flumen River to the North and East, (ii) the 2nd and 3rd sections of the first stretch of the Monegros Canal to the West, and (iii) the Barranco Las Negras to the South.

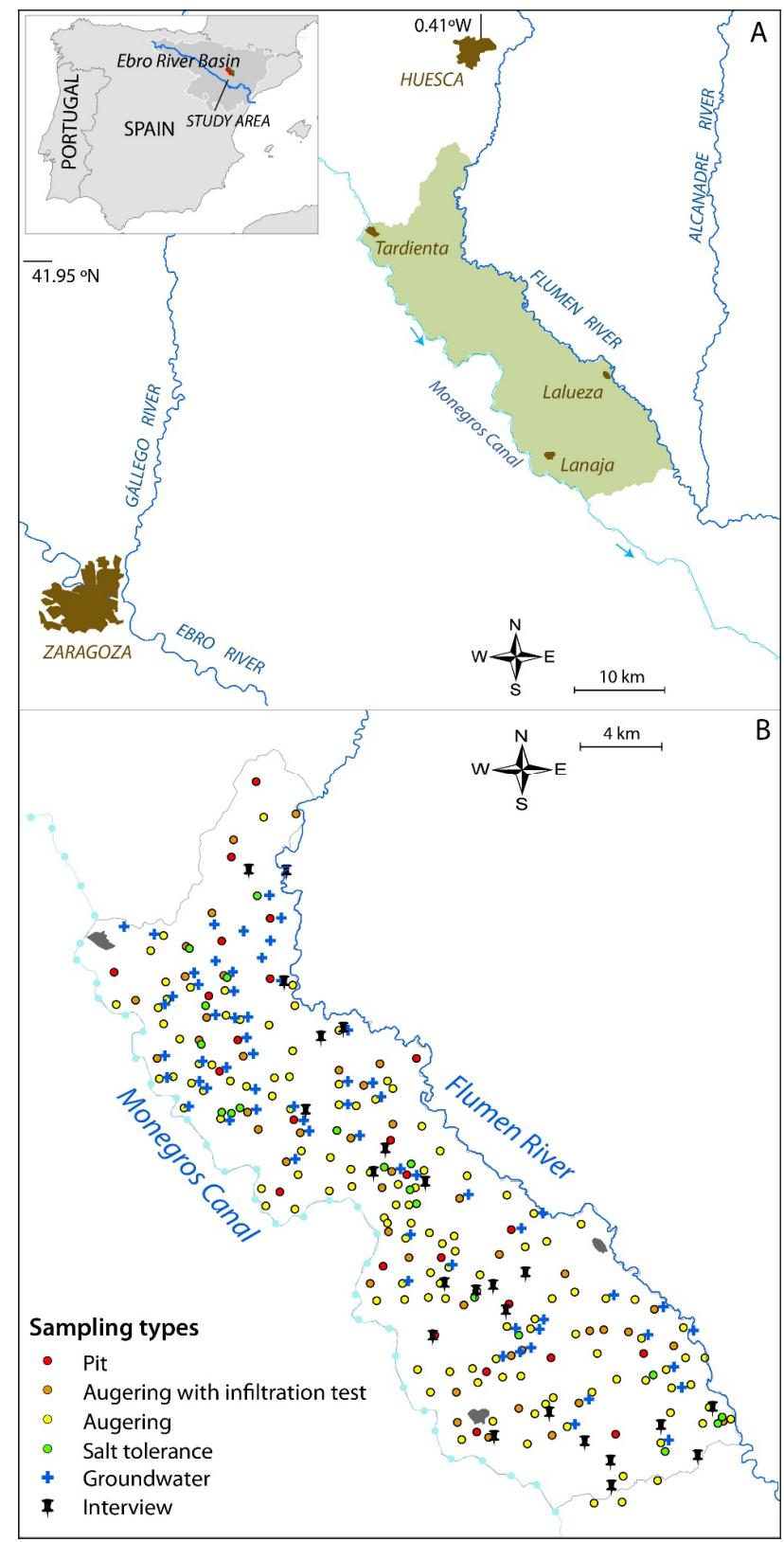

Figure 1. (A) Relative position of the district studied, colored in green, in the vicinity of the Monegros Canal, the rivers, and three main villages within the district. The inset shows the location of the district in Spain. (B) Location of the samplings and farmer interviews. 


\section{Subjects Addressed by the Report}

The main purpose of the report was "to locate the saline and non-saline soils", as explained in the Introduction section in [32]. The salinity is not the only subject studied, however, since the report follows a broad agronomical approach based on the state-of-theart methods established by the United States Department of Agriculture. The information in the report could shed a light on the trends in agriculture and the environment in this area.

The contents of each of the report's two volumes are summarized in Tables 1 and 2, and Figure 1B provides the location of each sample type and interviews with farmers.

Table 1. Chapters and maps in IRYDA [32].

\begin{tabular}{|c|c|}
\hline Chapters & Page \\
\hline 1. Background of the report & 1 \\
\hline 2. Conditions of the contract & 2 \\
\hline 3. Program and methods in the field, office, and lab & 4 \\
\hline 4. Climate & 11 \\
\hline 5. Geology and geomorphology & 18 \\
\hline 6. Agrohydrology: ground water, seepage and drainage, irrigation water & 29 \\
\hline 7. Natural vegetation and current use of land & 35 \\
\hline 8. Soils of the different geomorphic units & 41 \\
\hline 9. Soil salinity, and the tolerance of local crops & 63 \\
\hline 10. Recommendations for the irrigation and drainage systems & 73 \\
\hline 11. Land classification & 81 \\
\hline 12. Recommendations on the future use of the land and water; proposed crops & 89 \\
\hline 13. Recommendations for the future study of the saline soils & 97 \\
\hline 14. Summary and conclusions of the report & 100 \\
\hline \multicolumn{2}{|l|}{ Maps } \\
\hline Map 1. Location of the irrigation district; 1:400,000 scale & 115 \\
\hline $\begin{array}{l}\text { Map 2. Location of pits, auger holes, infiltration tests, hydraulic conductivity, and } \\
\text { farmer interviews; } 1: 50,000 \text { scale }\end{array}$ & 116 \\
\hline Map 3. Current land use; $1: 50,000$ scale & 117 \\
\hline Map 4. Geomorphic units; 1:50,000 scale & 118 \\
\hline Map 5. Land classes and levels of salinity-alcalinity; $1: 50,000$ scale & 119 \\
\hline
\end{tabular}

Table 2. Annexes in IRYDA [33].

\begin{tabular}{lc}
\hline \multicolumn{1}{c}{ Annexes } & Page \\
\hline 1. Bibliography consulted & 1 \\
2. Climatic data & 4 \\
3. Description of the soil profiles with their analytical data & 31 \\
4. Analytical data of the auger soil samples and graphs of pH, ECe, ESP & 133 \\
5. Analyses of the irrigation water on four dates, seven ground water samples from pits, & 156 \\
and 57 from augerings with their relationship with ECe & 239 \\
6. Permeability and infiltration measured in the field & 494 \\
7. Field interviews of farmers & 662 \\
8. Calculation of the water needed to desalinate the soil & 665 \\
9. Analyses of soil samples for determining crop tolerance to salinity-alkalinity &
\end{tabular}

\section{Scrutiny of the Material and Methods in the IRYDA Report}

\subsection{Soil Salinity and the Electrical Conductivity of the Soil}

The electrical conductivity (EC) of a soil: water extract is commonly used to estimate soil salinity. This was the method used in the report. The US Salinity Laboratory Staff [38] established the EC of the extract of a saturated paste of soils (ECe) to evaluate the effect of soil salinity on plant growth.

The US Salinity Laboratory Staff [38] also recommends EC1:5, i.e., the EC for a soil to water ratio of 1:5, to determine the change in salinity with time or treatment. The two-fixed dilutions approach [39] can help to refine the assessments of the stock of soluble salts in 
the soil. Nowadays, other methods can speed up the direct measurements of soil salinity by using modern sensors [40,41]. Advances in both instrumentation and methods can yield a wealth of new soil salinity data, whose comparison with heritage data will help in understanding and modeling the trend in salinity, a prime factor to the sustainability of agriculture in irrigated lands. The sustainable management of water and soils is a key strategy in the European Green Deal, supporting a whole host of EU policies in a variety of areas, from agriculture and food security to environmental protection.

The IRYDA report $[32,33]$ uses ECe to classify the soil profiles studied and to express the tolerance of crops to soil salinity. By contrast, the report uses EC1:5 to depict the soil salinity of the entire irrigation district. The IRYDA report [33], on pages 157-161, shows the major ions and several parameters of the irrigation water by monthly samplings in four consecutive months from May to July of 1975 at the start of the Monegros Canal. The mean electrical conductivity of the water was $0.38 \mathrm{dS} \mathrm{m}^{-1}$, ranging from $0.33 \mathrm{dS} \mathrm{m}^{-1}$ to $0.41 \mathrm{dS} \mathrm{m}^{-1}$, the mean $\mathrm{Na}^{+}$content was $6.7 \mathrm{dS} \mathrm{m}^{-1}$, and the sodium-adsorption-ratio (SAR) ranged from 0.5 to $0.6\left(\mathrm{mmol} \mathrm{L}^{-1}\right)^{0.5}$.

\subsection{Soil Analysis Methods in 1975}

The IRYDA laboratory in Madrid—closed in 1992-analyzed the 85 soil samples taken in the 24 soil profiles in pits described on pages 31 to 132 in Annex 3 of IRYDA [33]. The determinations were particle size distribution, organic matter, $\mathrm{pH}$, calcium carbonate, and soluble chloride. This lab also prepared the saturation extracts of these samples, determining their electrical conductivity $\left(\mathrm{ECe}, \mathrm{dS} \mathrm{m}^{-1}\right.$ ), and the content in meq $\mathrm{L}^{-1}$ of $\left(\mathrm{Ca}^{2+}+\mathrm{Mg}^{2+}\right)$ and $\mathrm{Na}^{+}$. We disregard here the determination of "soluble $\mathrm{Cl}^{- \text {" }}$ because the report does not provide the extraction method, and our consultation on 22 November 2001 with the last manager of the IRYDA lab was inconclusive. The lab of the private company "Unión Explosivos Río Tinto" determined the electrical conductivity of the 1:5 soil to water extracts by weight (EC1:5, $\mathrm{dS} \mathrm{m}^{-1}$ ) and the $\mathrm{pH}$ in water at a 1:1 soil to water dilution (pH1:1) for the samples of the augerings.

The IRYDA report [2] on pages 6-9 describes the analytical methods. We do not present the texture determinations because the report refers to "the Kilmer method" - perhaps [42] with unspecified variations. Annex 3 [33] describes the 24 soil profiles classified at the Subgroup level, as per the then-available version of Soil Taxonomy [43], and provides the percent of the particle-size separates. By contrast, the auger samples (Annex 4) only use Spanish terms to describe the texture, which are somewhat different from the USDA standard terms. At any rate, since the textures are time invariant, the data in the report might be useful for verification purposes in possible future destructive samplings. Similar considerations apply for the $\mathrm{pH}$ determinations.

The statistics of analytical data in this paper do not include the means of $\mathrm{pH}$ and SAR, because the non-additivity of these parameters make their means chemically unsound. Thus, we only present the median as a measure of centrality for $\mathrm{pH}$ and SAR.

\subsection{Soil Salinity Information Obtained from ECe Determinations}

The IRYDA report presents ECe determinations only in two batches of samples. Batch 1 contains the samples from the profiles described, and Batch 2 the ones collected for assessing the salinity tolerance of crops. The samples of both batches also have $\mathrm{Na}^{+}$ determinations.

\subsubsection{The Salinity in the Profiles Described in Pits}

Annex 3 in [33] contains descriptions of the 24 soil profiles studied in pits, and the analytical data of the fine earth samples, i.e., Batch 1 . The depth of the pits ranged from $165 \mathrm{~cm}$ to $33 \mathrm{~cm}$, with a mean of $129 \mathrm{~cm}$ and a median of $150 \mathrm{~cm}$. The statistics for the chemical determinations and SAR in the 85 samples (Table 3) are in agreement with our experience in CEB soils, e.g., [28]. 
Table 3. Statistics of the chemical data in the 85 soil samples from the 24 soil profiles described.

\begin{tabular}{|c|c|c|c|c|c|}
\hline & Minimum & Maximum & Mean & Median & $\begin{array}{c}\text { Mean Weighted by } \\
\text { Sample Depth Interval }\end{array}$ \\
\hline $\mathrm{ECe}, \mathrm{dS} \mathrm{m}^{-1}$ & 0.90 & 31.00 & 5.12 & 1.90 & 5.12 \\
\hline Organic matter, \% & 0.05 & 2.31 & 0.73 & 0.64 & 0.59 \\
\hline Calcium carbonate, $\%$ & 13.20 & 71.40 & 33.22 & 30.40 & 33.36 \\
\hline $\mathrm{pH}^{*}$ & 7.40 & 8.85 & - & 7.90 & - \\
\hline $\mathrm{Na}^{+}$, meg $\mathrm{L}^{-1}$ & 0.90 & 221.00 & 27.84 & 8.20 & 27.84 \\
\hline$\left(\mathrm{Ca}^{2+}+\mathrm{Mg}^{2+}\right)$, meq $\mathrm{L}^{-1}$ & 3.00 & 78.00 & 25.29 & 13.00 & 25.74 \\
\hline SAR $\left(\mathrm{mmol} \mathrm{L}^{-1}\right)^{0.5}$ & 0.40 & 35.30 & - & 3.50 & - \\
\hline
\end{tabular}

* Based on our consultation in 2001 with the last manager of the IRYDA lab, the pH was probably determined at a 1:2.5 soil to water dilution.

\subsubsection{Salinity in the Sampling for Salinity Tolerance of Crops}

Annex 9 in [33] shows the analytical results of 109 soil samples taken in plots of the main crops with different degrees of development attributed to soil salinity, i.e., Batch 2 . The depths of the augerings range from $49 \mathrm{~cm}$ to $120 \mathrm{~cm}$, with a mean of $70 \mathrm{~cm}$. The number of samples taken from each crop were: wheat, 25; barley, 26; oats, 9; corn, 18; rice, 12, and alfalfa, 19 .

The mean of the absolute values of the differences between the reported SAR and the SAR calculated by us from the data of $\mathrm{Na}^{+}$and $\left(\mathrm{Ca}^{2+}+\mathrm{Mg}^{2+}\right)$ is 0.31 units of SAR $\left(\mathrm{mmol} \mathrm{L}^{-1}\right)^{0.5}$. The strongest differences occurred at four samples (Table 4) from sites with poor crop development.

Table 4. Soil samples discarded when computing the statistics of determinations in the soil samples collected to establish the crops' tolerance to salinity.

\begin{tabular}{cccc}
\hline Augering No. & Depth, cm & Crop & Reported SAR Minus Calculated SAR \\
\hline 31 & $33-57$ & Barley & -4.75 \\
183 & $30-70$ & Oat & -7.93 \\
200 & $0-25$ & Barley & 11.93 \\
210 & $0-50$ & Corn & -3.05 \\
\hline
\end{tabular}

After checking that these differences were not due to typos or obvious transcription mistakes, we decided to discard the four samples when computing the statistics of the determinations in Batch 2 (Table 5).

Table 5. Statistics of the chemical data in 105 of the soil samples collected to establish the crops' tolerance to salinity.

\begin{tabular}{cccccc}
\hline & Minimum & Maximum & Mean & Median & $\begin{array}{c}\text { Mean Weighted by } \\
\text { Sample Depth Interval }\end{array}$ \\
\hline $\mathrm{ECe}, \mathrm{dS} \mathrm{m}{ }^{-1}$ & 0.60 & 19.00 & 5.47 & 4.20 & 5.39 \\
$\mathrm{Na}^{+}, \mathrm{meq} \mathrm{L}^{-1}$ & 0.80 & 143.40 & 25.95 & 6.80 & 25.70 \\
$\left(\mathrm{Ca}^{2+}+\mathrm{Mg}^{2+}\right), \mathrm{meq} \mathrm{L}^{-1}$ & 5.00 & 97.00 & 31.82 & 29.00 & 31.77 \\
$\mathrm{SAR}\left(\mathrm{mmol} \mathrm{L}^{-1}\right)^{0.5}$ & 0.20 & 50.40 & - & 2.10 & - \\
\hline
\end{tabular}

The overview of the soil salinity data from the IRYDA report provided by the statistics in Tables 3 and 5 point to concordant results of the analyses from both batches. These data give an indication of the salinity and other compositional data of the soil in 1975. However, due to the purpose and strategy of these samplings, they are not fully representative of the salinity in the entire district.

\subsubsection{Comparing ECe and $\mathrm{Na}^{+}$between the Two Batches of Samples}

The salinity data statistics of the two batches of samples with ECe and $\mathrm{Na}^{+}$determinations (Tables 3 and 5) are concordant, taking into account the different purposes of the two samplings. Both tables show negligible differences between the means of the analytical 
determinations calculated directly from the chemical data or from these data weighted by their sample depth interval.

The scatterplot of ECe versus $\mathrm{Na}^{+}$(Figure 2) shows a consistent distribution for the two batches of samples. The stacking of observations at the lower values of ECe in the scatterplot points to the presence of gypsum in some samples, with little to no sodium content, since this mineral can increase EC to about $2.5 \mathrm{dS} \mathrm{m}^{-1}$ in the saturation extracts.

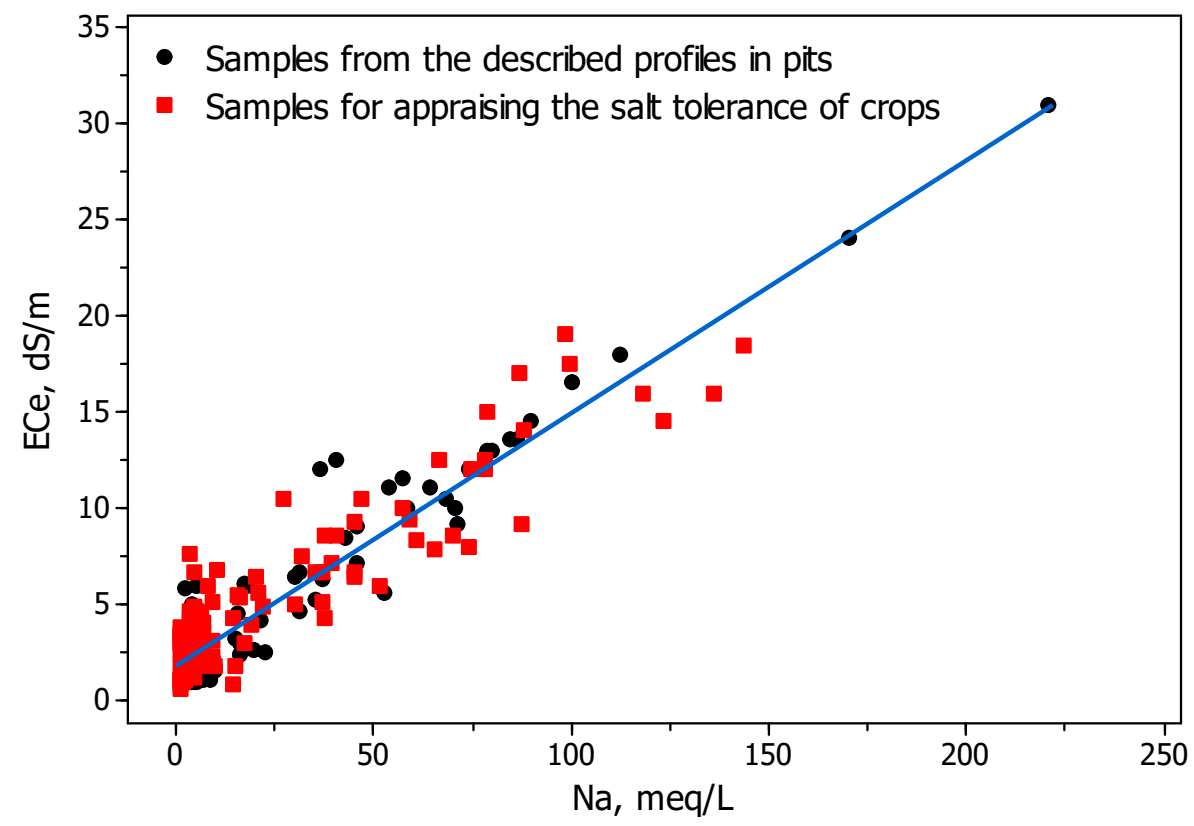

Figure 2. Scatterplot of ECe versus $\mathrm{Na}^{+}$for the 190 soil samples with $\mathrm{Na}^{+}$determinations. Table 6 shows the equation of the regression line in Equation (1).

Table 6. Regression equations of the shape ECe $=a+b$, with ECe in $\mathrm{dS} \mathrm{m}^{-1}$ and $\mathrm{Na}^{+}$in meq $\mathrm{L}^{-1}$, calculated for groups of $\mathrm{N}$ soil samples, with their coefficient of regression $\left(\mathrm{R}^{2}\right)$ in \%, and the standard error (SE) in $\mathrm{dS} \mathrm{m}^{-1}$.

\begin{tabular}{ccccccc}
\hline Computed Samples & $\mathbf{N}$ & $\boldsymbol{a}$ & $\boldsymbol{b}$ & $\mathbf{R}^{\mathbf{2}}$ & $\mathbf{S E}$ & \\
\hline Both batches together & 190 & 1.78 & 0.13 & 88.0 & 1.76 & Equation (1) \\
Only samples with ECe $>$ 2.5 & 111 & 3.24 & 0.11 & 86.7 & 1.84 & Equation (2) \\
Batch 1 & 85 & 1.13 & 0.14 & 93.2 & 1.50 & Equation (3) \\
Batch 2 & 105 & 2.34 & 0.12 & 83.4 & 1.84 & Equation (4) \\
\hline
\end{tabular}

For comparison purposes, we calculated the regression equations of ECe versus $\mathrm{Na}^{+}$ (Table 6), which yielded high regression coefficients for all the sample groups. Equation (2) eliminates from the calculation the samples having gypsum without more soluble salts; the similarity of Equations (1) and (2) supports a limited effect of gypsum on the regression. In the case of Batch 1, two outlier samples (Figure 2) strongly influence the regression. Both samples are from the soil surface: one is from pit $10(0-18 \mathrm{~cm})$, with $\mathrm{ECe}=31.0 \mathrm{dS} \mathrm{m}^{-1}$ and $\mathrm{Na}^{+}=221.0 \mathrm{meq} \mathrm{L}^{-1}$, and the other from pit $14(0-11 \mathrm{~cm})$, with $\mathrm{ECe}=24.0 \mathrm{dS} \mathrm{m} \mathrm{m}^{-1}$ and $\mathrm{Na}^{+}=171.5 \mathrm{meq} \mathrm{L}^{-1}$ (Figure 2), as per the analyses on pages 72 and 89 of the report [33]. These outlier samples explain the much higher coefficient of regression for Batch 1 (Equation (3)) than for Batch 2 (Equation (4)).

\subsection{The Stock of Soluble Salts in the Soil}

Annex 4 of the report [33] contains the analytical data of 519 soil samples taken with auger from 183 sites. The augerings are numbered in the report from 1 to 197, with 14 gaps or missing numbers: $13,29,31,48,125,145-152$, and 183. The depth of the augerings ranged from $20 \mathrm{~cm}$ to $230 \mathrm{~cm}$, with a mean of $108.4 \mathrm{~cm}$ and a median of $110 \mathrm{~cm}$. Site no. 96, 
described in the report as "surficial", had a disparately high EC1:5 of $14.5 \mathrm{dS} \mathrm{m}^{-1}$ (Figure 3), suggesting that this sample contained an efflorescence. For further computing, we assign to this sample a depth of $0-1 \mathrm{~cm}$.

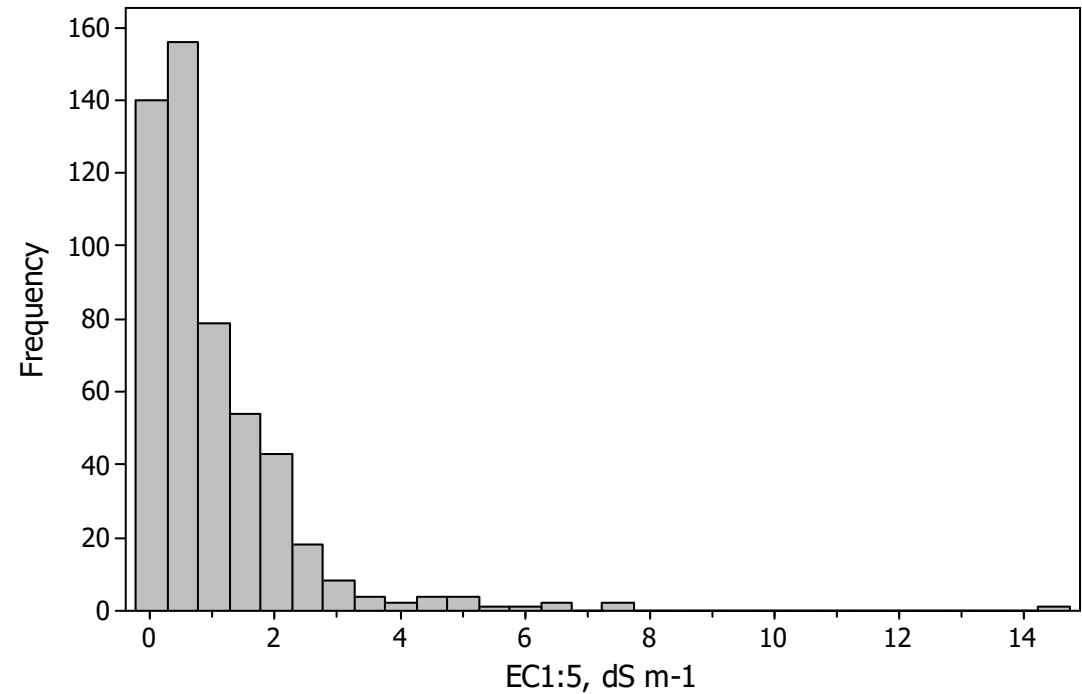

Figure 3. Histogram of EC1:5, dS $\mathrm{m}^{-1}$, for the 519 auger soil samples.

The EC1:5 of the 519 samples ranged from $0.11 \mathrm{dS} \mathrm{m}^{-1}$ to $14.5 \mathrm{dS} \mathrm{m}^{-1}$ with a mean of $0.99 \mathrm{dS} \mathrm{m}^{-1}$ and a median of $0.57 \mathrm{dS} \mathrm{m}^{-1}$; the mean of EC1:5 weighted by the sample depth interval was $0.95 \mathrm{dS} \mathrm{m}^{-1}$. The values of EC1:5 for the auger samples and the numbers assigned by us to each sample are available in the file "Augerings 1975 Monegros.docx" [44], The right-skewed distribution (Figure 3) is typical for the EC of soils.

We assess the stock of salts in the district from the 519 determinations of EC1:5 listed in pages 135-149 of Annex 4 [33] and collected in the file "Augerings 1975 Monegros.docx" [44]. In this table, we disregard ECe, despite the coefficient of determination $\mathrm{R}^{2}=89.6 \%$ of the ECe regression over EC1:5, because the ECe values were not determined in the lab, but estimated from EC1:5 by means of separate regressions for samples grouped by their texture. On pages 151 and 152 of [33], the report has two graphs, both with a poor adjustment, for different soil textures. Our scatterplot of ECe vs. EC1:5 for the 519 soil samples (not shown here) also evidences independent estimations by texture. Moreover, these estimates did not consider the presence of gypsum in some areas of the district, a circumstance that modifies the relationship ECe/EC1:5 [38,39,45]. Furthermore, ECe was conceived to express the salt stress on plants, while EC1:5 is a better proxy for total salt content in the soil [38,39]. A nontrivial advantage of EC1:5 is the simplicity of the method, which enhances the reliability of the determinations and their repeatability even in field-based laboratories. The Annex also contains the "ESP intervals", but we disregard this non-numerical information because ESP is supposedly an estimate from SAR, whose values are not provided in the report.

The above-mentioned file "Augerings 1975 Monegros.docx" [44] can be used to easily prepare tables of EC1:5 for customized depths. This kind of table would be necessary to calculate the stock of salts to arbitrary depths, as well as to match with new augering campaigns or with prospections using fixed-penetration instruments.

The $\mathrm{pH}$ in the 519 1:1 soil to water auger samples are shown in the file "Augerings 1975 Monegros.docx" [44], and in Figure 4. The $\mathrm{pH}$ ranges from 7.8 to 9.5, with a median of 8.30 . The values of $\mathrm{pH} 1: 1$ are hardly comparable with the $\mathrm{pH}$ of the 85 samples from the 24 soil profiles studied, whose dilution ratio was not ascertained, as noted at Table 3 . We could assume a dilution of 1:2.5, as per the official Spanish methods for soil analyses [46], but the distributions of the two sets of $\mathrm{pH}$ determinations are significantly different (Figure 4) and the $\mathrm{pH}$ values are higher in the auger samples. By contrast, the $\mathrm{pH}$ of the auger samples, as determined at a 1:1 dilution, would be expected to be lower than that of the pits if their 
dilution were 1:2.5 [47,48]. Due to these circumstances and to the limited value of $\mathrm{pH}$ for temporal comparisons of the stock of salts in the soil, we do not give further consideration in this article to the $\mathrm{pH}$ values.

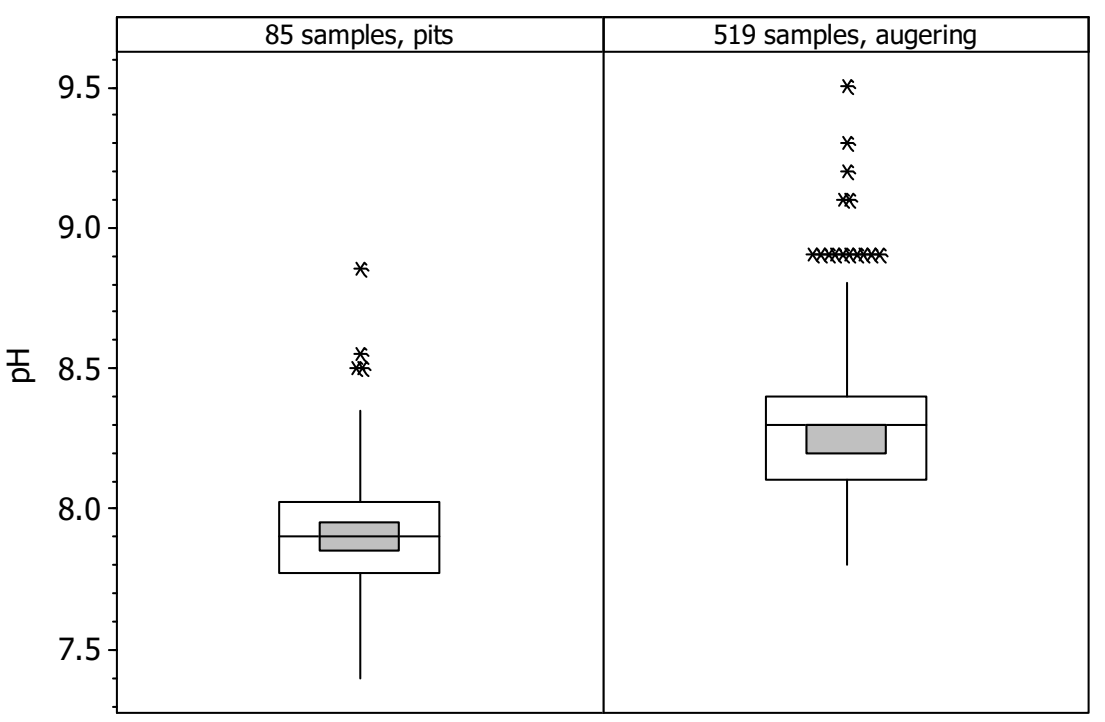

Figure 4. Boxplots of the $\mathrm{pH}$ measured in the 85 soil samples (unknown dilution) from the 24 soil profiles in pits described, and in the 519 samples from the 183 augering sites (1:1 dilution). The shaded square is the confidence interval of the median. The symbol * is for outliers.

\subsection{Location of the Soil Sampling Sites}

The soil surveyors had 278 contact prints of $23 \times 23 \mathrm{~cm}$ from the photogrammetric flight CETFA $57 / 72$ performed in May 1972. The prints, marked with colored wax crayon by the soil surveyors, had a scale of 1:10,000. The scans in PDF format of the 176 contact prints, which have marks from the surveyors for locating the sampling sites, plus the flight diagram are recorded in the file "Marked contacts CETFA Monegros1972 and diagram.zip" [44]. Most of the wax marks are crosses and dots indicating the sampling sites, but there are also other features, like village names and isolated boundary lines for some plots. The crayon strokes are about $2 \mathrm{~mm}$ thick, i.e., $\approx 20 \mathrm{~m}$ on the ground. This precision is allowable for the sampling sites since most of the smaller plots in the photographs are about $20 \mathrm{~m}$ wide. Moreover, a higher precision is not necessary, and it might even be undesirable, for repeated destructive paired samplings due to the localization paradox [49].

We established the UTM coordinates ETRS89 of the sites sampled in 1972 based on their representation in Map 2, yielding Figure 1B. The document used to georeference the sampling sites was the historic black and white orthophotographs of the OLISTAT Oleícola flight (1997-1998, scale 1:40,000, pixel size $1 \mathrm{~m}$ ), freely available at the National Center of Geographic Information (CNIG) (https:/ / centrodedescargas.cnig.es/CentroDescargas / catalogo.do?Serie=02211, accessed on 22 December 2021). The 34 control points between Map 2 and the OLISTAT mosaic allowed a mean error of $85 \mathrm{~m}$. The OLISTAT images have an acceptable quality and, since they were taken before the general shift to pressurized irrigation, they still allow for most of the plots sampled in 1972 to be easily identified. The entire irrigated district falls within the $100 \mathrm{~km}^{2}$ square 30T YM. The UTM coordinates obtained for the soil sampling sites are available at the file "Coordinates 1975 Monegros.docx" [44].

The incomplete matches between (i) sampling sites shown in Map 2 in [33], (ii) the list of sites, and (iii) the points marked on the contact prints used by the surveyors, makes it impossible to associate a few of the sample points with their analytical data, and vice versa. 


\section{Conclusions}

Our scrutiny of the report in question checks the consistency of the salinity data and makes accessible the status of the soil salinity stock of a $358 \mathrm{~km}^{2}$ irrigation district in 1975. Moreover, we establish the UTM coordinates of the sampling sites, absent in the IRYDA report. The rescued data make it possible to evaluate the salinity changes in the district by comparison with other soil salinity surveys conducted - or to be conductedon other dates. Future appraisals might use paired samplings, whether destructive or based on proximal sensors or other prospection instruments or techniques to come. The operative combination with remote and proximal sensing techniques is foreseeable. In any case, any forthcoming appraisals will be cheaper and easier to make than the 1975 survey, allowing for the regular monitoring of salinity. We hope that this article will encourage environmental and agricultural agencies, as well as the researchers and stakeholders of the irrigation district, to undertake new appraisals of soil salinity to illustrate the outcomes of irrigation and eventually design corrective or preventive actions.

Author Contributions: J.H. and C.C. wrote the text. R.G.-B. curated the numerical data producing Excel files ready for analysis. All authors have read and agreed to the published version of the manuscript.

Funding: Grant PCI2018-09299 funded by MCIN/AEI/10.13039/501100011033 and co-funded by the European Union.

Data Availability Statement: Data are free available at Mendeley Data, V3, doi:10.17632/2rz97fkmzr.3.

Acknowledgments: M.C. Pou provided info about the now-closed lab of IRYDA.

Conflicts of Interest: The authors declare that they have no competing interests or personal relationships that could have appeared to influence the work reported in this article. The funders had no role in the design of this study, in the interpretation of data, in the writing of the manuscript, or in the decision to publish.

\section{Abbreviations \\ CEB: Central Ebro Basin; CHE: Ebro Basin Water Authority; EC: electrical conductivity; EC1:5: electrical conductivity of a soil to water solution 1:5 in weight; ECe: electrical conductivity of the extract of saturation paste; SAR: sodium-adsorption-ratio.}

\section{References}

1. Hopmans, J.W.; Qureshi, A.S.; Kisekka, I.; Munns, R.; Grattan, S.R.; Rengasamy, P.; Ben-Gal, A.; Assouline, S.; Javaux, M.; Minhas, P.S.; et al. Critical knowledge gaps and research priorities in global soil salinity. Adv. Agron. 2021, 169, 1-191. [CrossRef]

2. Stavi, I.; Thevs, N.; Priori, S. Soil salinity and sodicity in drylands: A review of causes, effects, monitoring, and restoration measures. Front. Environ. Sci. 2021, 9, 712831. [CrossRef]

3. FAO. Global Map of Salt-Affected Soils; GSASmap v1.0.0; FAO: Rome, Italy, 2021. Available online: https://www.fao.org/soilsportal/data-hub/soil-maps-and-databases/global-map-of-salt-affected-soils/en/ (accessed on 22 December 2021).

4. Daliakopoulos, I.N.; Tsanis, I.K.; Koutroulis, A.; Kourgialas, N.N.; Varouchakis, A.E.; Karatzas, G.P.; Ritsema, C.J. The threat of soil salinity: A European scale review. Sci. Total Environ. 2016, 573, 727-739. [CrossRef]

5. Ayers, A.D.; Vázquez, A.; De la Rubia, J.; Blasco, F.; Samplón, S. Saline and sodic soils of Spain. Soil Sci. 1960, 90, 133-138. [CrossRef]

6. Cervera-Álvarez, R. Los suelos salinos de la Depresión del Ebro. Boletín Asoc. Nac. Ing. Agrónomos 1966, 167, 193-199.

7. Grande-Covián, R. Las Marismas del Guadalquivir y su Rescate; Colección Estudios 5 (29); Ministerio de Agricultura, Instituto Nacional de Colonización: Madrid, Spain, 1967; 64p.

8. Zekri, S.; Albisu, L.M. Economic impact of soil salinity in agriculture. A case study of Bardenas area, Spain. Agric. Syst. 1993, 41, 369-386. [CrossRef]

9. Calvo, E.; Feijóo, M.L.; Mema, M.; Albiac, J. La influencia de la Política Agrícola Común en la zona de Regadío Flumen-Monegros. Estud. Econ. Appl. 1999, 13, 5-22.

10. Castañeda, C.; Herrero, J.; Latorre, B. The vanishing legacy of soil salinity data from irrigated districts: A case study from Spain and a call for action. Adv. Agron. 2020, 161, 325-355. [CrossRef]

11. Berbel, J.; Expósito, A.; Gutiérrez-Martín, C.; Mateos, L. Effects of the irrigation modernization in Spain 2002-2015. Water Resour. Manag. 2019, 33, 1835-1849. [CrossRef] 
12. Filippi, P.; Cattle, S.R.; Bishop, T.F.A.; Pringle, M.J.; Jones, E.J. Monitoring changes in soil salinity and sodicity to depth, at a decadal scale, in a semiarid irrigated region of Australia. Soil Res. 2018, 56, 696-711. [CrossRef]

13. Ivushkin, K.; Bartholomeus, H.; Bregt, A.; Pulatov, A.; Kempen, B.; De Sousa, L. Global mapping of soil salinity change. Remote Sens. Environ. 2019, 231, 111260. [CrossRef]

14. Hassani, A.; Azapagic, A.; Shokri, N. Predicting long-term dynamics of soil salinity and sodicity on a global scale. Proc. Natl. Acad. Sci. USA 2020, 117, 33017-33027. [CrossRef]

15. Cruz-Lapazarán, J. El fundamento del concurso de material de nivelación de Tardienta. Rev. Confed. Sind. Hidrográfica Ebro 1927, $1,8-9$.

16. Casterad, M.A.; Herrero, J. Irrivol: A method to estimate the yearly and monthly water applied in an irrigation district. Water Resour. Res. 1998, 34, 3045-3049. [CrossRef]

17. Nogués, J.; Herrero, J.; Rodríguez-Ochoa, R.; Boixadera, J. Land evaluation in a salt-affected irrigated district using an index of productive potential. Environ. Manag. 2000, 25, 143-152. [CrossRef] [PubMed]

18. Sumner, M.E. Soil testing and plant analysis: Building a future on our legacy. Commun. Soil Sci. Plant Anal. 2006, 37, $2277-2287$. [CrossRef]

19. De Bruyn, L.L.; Jenkins, A.; Samson-Liebig, S. Lessons learnt: Sharing soil knowledge to improve land management and sustainable soil use. Soil Sci. Soc. Am. J. 2017, 81, 427-443. [CrossRef]

20. Minai, J.O.; Schulze, D.G.; Libohova, Z. Renewal of archival legacy soil data: A case study of the Busia Area, Kenya. Front. Soil Sci. 2021; in press. [CrossRef]

21. Hawkins, S.J.; Firth, L.B.; McHugh, M.; Poloczanska, E.S.; Herbert, R.J.H.; Burrows, M.T.; Kendall, M.A.; Moore, P.J.; Thompson, R.C.; Jenkins, S.R.; et al. Data rescue and re-use: Recycling old information to address new policy concerns. Mar. Policy 2013, 42, 91-98. [CrossRef]

22. Schröder, J.J.; Ten Berge, H.F.M.; Bampa, F.; Creamer, R.E.; Giráldez-Cervera, J.V.; Henriksen, C.B.; Olesen, J.E.; Rutgers, M.; Sanden, T.; Spiegel, H. Multi-functional land use is not self-evident for European farmers: A critical review. Front. Environ. Sci. 2020, 8, 575466. [CrossRef]

23. Nogués, J.; Robinson, D.A.; Herrero, J. Incorporating electromagnetic induction methods into regional soil salinity survey of irrigation districts. Soil Sci. Soc. Am. J. 2006, 70, 2075-2085. [CrossRef]

24. Paz, A.M.; Castanheira, N.; Farzamian, M.; Paz, M.C.; Gonçalves, M.C.; Monteiro Santos, F.A.; Triantafilis, J. Prediction of soil salinity and sodicity using electromagnetic conductivity imaging. Geoderma 2020, 361, 114086. [CrossRef]

25. Zare, S.; Abtahi, A.; Shamsi, S.R.F.; Lagacherie, P. Combining laboratory measurements and proximal soil sensing data in digital soil mapping approaches. Catena 2021, 207, 105702. [CrossRef]

26. Tokumoto, I.; Chiba, K.; Mizoguchi, M. Soil salinity management using a Field Monitoring System (FMS) in tsunami-affected farmlands in Miyagi, Japan. Int. Agrophys. 2021, 35, 227-231. [CrossRef]

27. Peddinti, S.R.; Hopmans, J.W.; Najm, M.A.; Kisekka, I. Assessing effects of salinity on the performance of a low-cost wireless soil water sensor. Sensors 2020, 20, 7041. [CrossRef]

28. Herrero, J.; Pérez-Coveta, O. Soil salinity changes over 24 years in a Mediterranean irrigated district. Geoderma 2005, 125, 287-308. [CrossRef]

29. Mora, J.L.; Herrero, J.; Weindorf, D.C. Multivariate analysis of soil salination-desalination in a semi-arid irrigated district of Spain. Geoderma 2017, 291, 1-10. [CrossRef]

30. Herrero, J.; Castañeda, C. A legacy of quantitative and qualitative data for the irrigated Violada Area and conterminous lands in Aragon, Spain. Agronomy 2021, 11, 799. [CrossRef]

31. Herrero, J.; Castañeda, C. Data supporting the soil salinity evolution appraisals in the Flumen irrigation district, NE Spain. Data Brief 2021, 37, 107171. [CrossRef] [PubMed]

32. IRYDA. Estudio de Suelos del $2^{\circ}$ y 3er Tramo de La Zona Regable de Los Monegros, Huesca. Volume I: Memory and Plans, 113 Pages. 1975. Available online: http:/ / dara.aragon.es/opac/app/item/ahph?vm=nv\&p=0\&st=.3.115.119.154.179\&i=1048567 (accessed on 22 December 2021).

33. IRYDA. Estudio de Suelos del $2^{\circ}$ y 3er Tramo de la zona regable de Los Monegros, Huesca. Volume II: Annexes, 671 Pages. 1975. Available online: https:/ / dara.aragon.es/opac/app/item/ahph?vm=nv\&p=0\&st=.3.115.119.154.179\&i=1048568 (accessed on 22 December 2021).

34. CHE (Confederación Hidrográfica del Ebro). Plan Hidrológico. Documentación Básica. Memoria 1, 321 Pages. Zaragoza, Spain. 1988. Available online: http://www.chebro.es/contenido.visualizar.do?idContenido=17381\&idMenu=3400 (accessed on 22 December 2021).

35. Humphries, R.N.; Brazier, R.E. Exploring the case for a national-scale soil conservation and soil condition framework for evaluating and reporting on environmental and land use policies. Soil Use Manag. 2018, 34, 134-146. [CrossRef]

36. Kibblewhite, M.G.; Chambers, B.J.; Goulding, K.W.T. How good is the evidence to support investment in soil protection? Soil Use Manag. 2016, 32 (Suppl. 1), 172-182. [CrossRef]

37. Lecina, S.; Isidoro, D.; Playán, E.; Aragüés, R. Irrigation modernization and water conservation in Spain: The case of Riegos del Alto Aragón. Agric. Water Manag. 2010, 97, 1663-1675. [CrossRef]

38. United States Salinity Laboratory Staff. Diagnosis and Improvement of Saline and Alkali Soils; Agriculture Handbook 60; USDA: Washington, DC, USA, 1954. 
39. Herrero, J.; Weindorf, D.C.; Castañeda, C. Two fixed ratio dilutions for soil salinity monitoring in hypersaline wetlands. PLoS ONE 2015, 10, e0126493. [CrossRef]

40. Weindorf, D.C.; Chakraborty, S.; Herrero, J.; Li, B.; Castañeda, C.; Choudhury, A. Simultaneous assessment of key properties of arid soil by combined PXRF-VisNIR data. Eur. J. Soil Sci. 2016, 67, 173-183. [CrossRef]

41. Corwin, D.L.; Scudiero, E. Review of soil salinity assessment for agriculture across multiple scales using proximal and/or remote sensors. Adv. Agron. 2019, 158, 1-130. [CrossRef]

42. Kilmer, V.J.; Alexander, L.T. Methods of making mechanical analyses of soils. Soil Sci. 1949, 68, 15-24. [CrossRef]

43. Soil Survey Staff. 7th Approximation to Soil Taxonomy System: Soil Survey Staff; US Department of Agriculture: Washington, DC, USA, 1960.

44. Herrero, J. Soil Salinity in 1975 in an Irrigated District Watered by the 2nd and 3rd Sections of the First Part of Monegros Canal (Huesca, Spain). Mendeley Data, V3. 2021. Available online: https://doi.org/10.17632/2rz97fkmzr.3 (accessed on 22 December 2021).

45. Visconti, F.; De Paz, J.M.; Rubio, J.L. What information does the electrical conductivity of soil water extracts of 1 to 5 ratio $(w / v)$ provide for soil salinity assessment of agricultural irrigated lands? Geoderma 2010, 154, 387-397. [CrossRef]

46. BOE (Boletín Oficial del Estado). Orden de 5 de Diciembre de 1975 por la que se Aprueban como Oficiales los Métodos de Análisis de Suelos y Aguas; Ministerio de Agricultura: Madrid, Spain, 1976; pp. 6458-6491. Available online: https://www.boe.es/ (accessed on 22 December 2021).

47. Peech, M. Hydrogen-ion activity. In Methods of Soil Analysis: Part 2: Chemical and Biological Properties; Black, C.A., Ed.; Soil Science Society of America: Madison, WI, USA, 1965; pp. 914-926.

48. Al-Bousaidi, A.; Cookson, P.; Yamamoto, T. Methods of $\mathrm{pH}$ determination in calcareous soils: Use of electrolytes and suspension effect. Aust. J. Soil Res. 2005, 43, 541-545. [CrossRef]

49. Herrero, J.; Netthisinghe, A.; Hudnall, W.H.; Pérez-Coveta, O. Electromagnetic induction as a basis for soil salinity monitoring in a Mediterranean irrigated district. J. Hydrol. 2011, 405, 427-438. [CrossRef] 